\title{
NYÍRSÉGI MACROHETEROCERA EGYÜTTESEK VIZSGÁLATA ILLATANYAGCSAPDÁK ALKALMAZÁSÁVAL
}

\author{
Szanyi Szabolcs', Molnár Attila², Kozák Lajos ${ }^{3}$, Szalárdi Tímea1, Varga Zoltán4, \\ Tóth Miklós ${ }^{5}$ és Nagy Antal ${ }^{1}$ \\ ${ }^{1}$ Debreceni Egyetem, MÉK, Növényvédelmi Intézet \\ 2II. Rákóczi Ferenc Kárpátaljai Magyar Főiskola, Biológia és Kémia Tanszék \\ ${ }^{3}$ Debreceni Egyetem, MÉK, Természetvédelmi Állattani és Vadgazdálkodási Tanszék \\ ${ }^{4}$ Debreceni Egyetem, Evolúciós Állattani és Humánbiológiai Tanszék \\ ${ }^{5}$ Magyar Tudományos Akadémia, ATK, Növényvédelmi Intézet
}

\begin{abstract}
Kivonat
A Nyírség karakterisztikus élővilága leginkább a növényvilág tekintetében kutatott, míg a terület állatvilága, különösen a rovarvilág kevéssé ismert. Ez igaz a terület lepkefaunájára is, amit jórészt 20 évnél is régebbi vizsgálatok alapján ismerünk. A korábbi fénycsapdás mintavételekkel szemben 2014-2015-ben illatanyag csapdák alkalmazásával vizsgáltuk a Dél-Nyírség Macroheterocera faunáját Debrecen-Nagycserén végzett mintavételezés révén. Célunk a használt izoamil-alkohol (FERM) és fenilacetaldehid (FLORAL) alapú csalétkek hatékonyságának és szelektivitsának összevetésén túl a terület hiányzó faunisztikai adatinak pótlása volt. A két évben 7 lepkecsalád összesen 226 fajának jelenlétét mutattuk ki a területen. A csapdák legnagyobb számban Noctuidae fajokat vonzottak. A fajszámok tekintetében a FERM csalétkek voltak hatékonyabbak, de kimutatható volt a csalétkek eltérő hatékonysága is. A kapott adatok alapján elvégeztük a vizsgált fauna faunaelem és faunakomponensek szerinti jellemzését is.
\end{abstract}

Kulcsszavak: illatanyag csapda, Noctuidae, fauna, faunaelem, faunakomponens.

\section{STUDY ON THE MACROHETEROCERA ASSEMBLAGES OF THE NYÍRSÉG (NORTHEAST HUNGARY) USING VOLATILE TRAPS}

\begin{abstract}
The unique biota of the Nyirség region is known mainly on basis of its flora, however, its fauna is poorly studied especially in case of insects, for the Lepidoptera fauna we have only more than 20-years old data collected by light traps. In 2014 and 2015 we carried out samplings with volatile traps near Debrecen-Nagycsere, in the southern part of the Nyírség. We attempted to compare comparing the efficiency and selectivity of phenylacetaldehyde based (FLORAL) and isoamyl-alcohol based (FERM) lures, and to collect faunistical data from teh region. During the two-years long study we caught 226 Macroheterocera species belonging to 7 familes. Considering the number of caught species the FERM bait was more effective and the different selectivity of the lures was also proven. We characterised the studied fauna on the basis of their composition and ratios of faunal types and faunal components.
\end{abstract}

Keywords: volatile traps, Noctuidae, fauna, faunal elements, faunal components. 


\section{BEVEZETÉS}

A Nyírség különösen annak déli része - a Szatmár-Beregi síkhoz hasonlóan - még a múlt század első felében is zömmel erdős, lápokkal tarkított táj volt. Domborzati és talajtani viszonyai azonban sokkal változatosabbak, és növényzetének sokszínűsége is kiemeli az Alföld többi részétől. Ebből adódóan már a XX. század elejétől rendszeresen kutatják a botanikusok, melynek eredményeiröl számos mü látott napvilágot (Boros 1932, Soó 1934, 1937, 1938, 1939a, 1939b, 1943, Papp \& Dudás 1989a, 1989b, Matus \& Papp 2003). Ezzel szemben a terület zoológiai feltárása - a Bátorligeti lápot és környékét kivéve - még ma sem történt meg kellő részletességgel. Különösen igaz ez a régió nagylepke faunájára, melyröl a legalaposabb felmérés Bátorligeten és környékén történt még az 1950-es években (Kovács 1953), majd később ezt a munkát megismételték (Ács et al 1991), de mára ezek a fiatalabb adatok is réginek számítanak. Az itt előkerült fajok jórésze az egész Nyírségre jellemző, azonban a növénytársulások sokszínűsége és mozaikos szerkezete miatt az eredmények nem általánosíthatók (Varga 1957). Ugyan időszakos fénycsapdás/lámpázásos gyüjtéseket zömmel a Nyírség déli részén és az ahhoz csatlakozó hajdúsági területeken (Varga 1957, 1960a, 1960b, 1962, Baranyi 2003, Baranyi et al 2002, 2004, 2005) végeztek azóta is, azonban rendszeres, több éven át tartó kvantitatív vizsgálatok mindeddig nem történtek.

A korábbi mintavételek kizárólag fénycsapdás módszerrel folytak, amely csak a fényre pozitívan reagáló fajokra hat, így ahhoz, hogy teljes képet kapjunk az itt elöforduló fajegyüttesről, érdemes más módszereket, például valamilyen csalétket is alkalmazni. A csalétekkel működő csapdák alkalmazása nagy múltra tekint vissza. A korai időkben gyakori volt a sör, bor, cukor vagy méz elegyek különböző kombinációinak alkalmazása (Kelecsényi 1885, Abafi-Aigner 1907, Mészáros \& Vojnits 1972, Petrich 2001). A faunisztikai kutatásokban a XX. század második felétől kezdve a csalétkes csapdák alkalmazása fokozatosan visszaszorult. Később azonban a növényvédelmi elörejelzésben elterjedt feromoncsapdák mellett egyre nagyobb jelentőséget kaptak a táplálkozási ingereket használó csalétkek is, mivel ezek szélesebb fajspektrumot vonzanak, és mindkét ivar egyedeit egyaránt a csapdákba csalogatják, segítve ezzel a kártevők ellenei hatékony védekezést is.

Az első tesztek során a fenilacetaldehid bagolylepke nőstényekre gyakorolt vonzó hatása (Cantelo \& Jacobson 1979) vált ismerté, majd az izoamil-alkohol alapú csalétkek hatékonyságát bizonyították Észak-Amerikában végzett kísérletekben (Landolt 2000, Landolt \& Alfaro 2001). Az említett komponensekkel és elegyekkel végzett, azok hatékonyságát megerősitő magyarországi vizsgálataik eredményét Tóth Miklós és munkatársai néhány éve mutatták be (Tóth et al 2010). Tesztjeik során az említett komponensek összevetését, és az azok hatását esetlegesen növelő egyes szinergista anyagok vizsgálatát is elvégezték. A tesztekben a fenilacetaldehid csalétkek föleg a Plusiinae és a Melicleptriinae, míg az izoamil-alkohol alapú csalétkek más alcsaládok, például a Noctuinae és a Hadeninae fajait vonzották (Nagy et al 2014, Szanyi et al 2017). A fogott fajok viszonylag magas száma lehetőséget ad arra, hogy a csalétkeket kártevő fajok előrejelzésén túl, a faunisztikai és közösségökológiai vizsgálatokban is alkalmazzuk. 
Munkánk során különböző illatanyagokat tartalmazó csapdákat helyeztünk ki a Dél-Nyírségben Debrecen-Nagycsere területén. Célunk az illatanyagok hatékonyságának és szelektivitásának tesztelése mellett a hiányzó faunisztikai adatok pótlása volt.

\section{ANYAG ÉS MÓDSZER}

\section{Mintavételi terület}

A mintavételi terület Debrecen-Nagycsere külterületén a településtöl északkeletre mintegy 800 méterre, és a 48-as főúttól mintegy 400 méterre északra helyezkedett el $\left(47^{\circ} 31,802^{\prime}\right.$ É; $\left.21^{\circ} 47,027^{\prime} \mathrm{K}\right)$. A csapdákat egy elegyes lomberdő és egy akácos szegélyében, lineáris transzekt mentén helyeztük ki. A transzekt közvetlen közelében az erdő szegélyén marhalegelö, akácos újulat és vízelvezető árok, valamint az azt szegélyező cserjés volt jelen. A tágabb környezetben egy védett elegyes erdőfolt volt található, ami még őrzi a Nyírségre jellemző pusztai tölgyesek jellemzőit, a többi környező erdő viszont nagyrészt fiatal telepítésű, erősen gyomosodó aljnövényzetű nemesnyáras, illetve kisebb részben akáctelepítés volt. A fátlan társulások közül is inkább a bolygatott élöhelytípusok voltak a jellemzőek: szarvasmarha legelő, különböző gyakori kultúrákkal (kukorica, napraforgó) telepített, valamint felhagyott szántók és legelők. A csapdák kihelyezésénél a legfontosabb cél az volt, hogy azok a területre jellemző mozaiktáj jellegzetes élőhelyeinek minél szélesebb spektrumáról gyüjthessenek lepkefajokat.

\section{Módszer}

A terepi mintavételekre 2014. július 24. és október 12., valamint 2015. május 23. és október 31. között került sor. A csapdázást CSALOMON ${ }^{\circledR}$ VARL+ típusú varsás csapdákkal végeztük. A kísérlet során két táplálkozási attraktánst alkalmaztunk (FERM és FLORAL), illetve csalétek nélküli kontroll (UNB) csapdákat is kihelyeztünk.

A FERM nevü félszintetikus csalétek azonos volt a Tóth et al (2015) által leírtakkal, kibocsátójaként CHR diszpenzert, azaz egy $4 \mathrm{ml}$ befogadó képességü, $0,2 \mathrm{~mm}$ falvastagságú, müanyag fecskendőhöz hasonló polipropilén csövet használtunk, melybe fogorvosi tampont helyeztünk. Az illatanyag, ami izoamil alkohol, ecetsav és vörösbor elegye volt (1:1:1, $3 \mathrm{ml})$ ebben a tamponban került felitatásra. Kihelyezéskor a tubus alsó részén levő vékony csövecskét levágva, $4 \mathrm{~mm}$ átmérőjü rés keletkezett, melyen keresztül a hatóanyagok kipárologhattak. A FLORAL nevü szintetikus csalétek kibocsátója Tóth et al (2010) szerint egy 1,5×1,5 cm-es polietilén tasak volt, melybe fogászati tampon darabka került. 2014-ben a csapdákba két külön diszpenzerben volt elhelyezve az illatanyag. Az egyikben fenilacetaldehid és $(E)$ anetol, 1:1 arányú, a másikban fenilacetaldehid, eugenol és benzil acetát 1:1:1 arányú elegye volt. 2015-ben pedig már csak az utóbbi csalétek került a csapdákba. Az illatanyag a 
0,02 mm-es vastagságú polietilén tasak falán keresztül párolgott a környezetbe a kihelyezést követően.

Minden csalétekkel szerelt csapdában egy-egy, illetve 2014-ben a FLORAL csapdákba két-két diszpenzert helyeztünk el. A kezeléseket (FERM, FLORAL, Kontroll) négy ismétlésben blokkokban helyeztük el transzekt mentén, ami összesen $12\left(4^{*} 3\right)$ csapdát jelentett. A csapdákat a talajfelszíntől mintegy 1,5 méteres magasságban erdőszéli fákra, cserjékre rögzítettük, egymástól mintegy $15 \mathrm{~m}$ távolságban. A blokkokon belül a csapdák sorrendje állandó volt, így az azonos csapdák mintegy 45 méterre voltak egymástól. A csapdákat hetente egy alkalommal ellenőriztük, a csalétkeket háromhetente cseréltük. A csapdahely fogásokat torzító hatásának elkerülésére a csapdákat minden ellenőrzés alkalmával eggyel eltoltuk a transzekt mentén (rotáltuk). A csapdába került egyedekkel molyirtó csík végzett (Chemotox®, SaraLee, Temana Intl. Ltd., South UK; hatóanyag 15\% dichlorvos).

A befogott anyagot a laboratóriumi feldolgozásig mélyhütőben tároltuk. A fogott Macroheterocera anyagot a fajösszetétel és a faunaelemek, valamint a faunakomponensek megoszlása alapján jellemeztük. Ehhez a „A Magyar Állatvilág Fajjegyzéke” 3. kötetét (Varga et al 2004) használtuk. Emellett kiemeltük és jellemeztük a faunisztikai és természetvédelmi szempontból jelentősnek itélt fajokat. A nevezéktanban és a fajok jellemzésében a „Magyarország Nagylepkéi" címü kötetet vettük alapul (Varga 2011).

\section{EREDMÉNYEK ÉS ÉRTÉKELÉSÜK}

2014-ben és 2015-ben Nagycserén összesen 226 lepkefaj jelenlétét sikerült kimutatni (1. táblázat). A használt félszintetikus izoamil-alkohol alapú (FERM) csalétek 182, míg a szintetikus fenilacetaldehid alapú (FLORAL) 120 faj egyedeit vonzotta. A használt illatanyagok leginkább az aktívan táplálkozó fajok egyedeit vonzzák, így nem meglepő, hogy a Noctuidae, valamint a Geometridae és Erebidae családok esetében mutattak nagyobb hatékonyságot (2. Táblázat, $1 \mathrm{~A}$. ábra). A használt illatanyagok specifitása a fajszámokban és a fogott egyedszámokban is megmutatkozott. A fogott fajok száma a FERM esetén csaknem másfélszerese volt a FLORAL által vonzott fajoknak. A közös fajok száma 78, a csak FERM által vonzottaké 104, míg ez a szám a FLORAL esetén ennek kevesebb, mint fele (42 faj) volt. A legjelentősebb eltérés a Noctuidae család esetén volt megfigyelhetö. Itt a 143 fogott fajból 77, azaz több mint a fajok fele csak a FERM illatanyagra repült, míg a FLORAL esetén a differenciális fajok száma mindössze 16 volt. A Thyatiridae és az Erebidae családok esetén szintén a FERM illatanyag vonzó hatása érvényesült, míg a Geometridae fajok egyértelműen a FLORAL-t preferálták (2. táblázat). A jelzett különbségek a tömegviszonyokban is jól megmutatkoztak (1A. ábra). A Noctuidae családon belül az illatanyagok eltérő szelektivitása szintén megmutatkozott. A FERM illatananyag a Xyleninae, Noctuinae, Hadeninae és Acronictinae alcsaládok fajait vonzotta nagyobb számban, míg a FLORAL a Plusiinae alcsalád fajaival szemben mutatott nagyobb hatékonyságot. A jelzett különbségek a fajszámok és a fogott egyedszámok alapján egyaránt jól kirajzolódtak (2. táblázat és 1b. ábra). Mivel csak 
két év vizsgálati eredményei állnak rendelkezésünkre a további mintavételektöl, a fogott fajszám növekedését várjuk.

1. táblázat: A Debrecen-Nagycserén 2014-ben és 2015-ben illatanyagos csapdákkal gyüjtött Macroheterocera fajok jegyzéke, faunaelem és faunakomponens besorolása és megoszlásuk a használt félszintetikus (FERM) és szintetikus (FLORAL) biszex csalétekkel szerelt csapdák között.

Faunaelemek: Eu: euro-, Sib: szibériai, Med: Mediterrán, Bor: boreo-, Kont: kontonentális, Ext: etra,

Pal: palearktikus, P: pontusi, Kasz:kaszpi, M: mandzsúriai, Szubt: szubtrópusi;

Faunakomponensek: Altoherb.: altoherbosa, Pop-Salic.: Populo-Salicetalis, Lápr-Lápe.: Lápréti-Láperdei, Betulo-aln.: Betulo-alnetális, V: védett, F: faunisztikailag jelentős.

\begin{tabular}{|c|c|c|c|c|}
\hline Fajok & Faunaelem & $\begin{array}{c}\text { Fauna } \\
\text { komponens }\end{array}$ & FERM & FLORAL \\
\hline \multicolumn{5}{|l|}{ Sphingidae } \\
\hline Deilephila elpenor (Linnaeus, 1758). & Eu-Sib & Altoherb. & 3 & \\
\hline Macroglossum stellatarum (Linnaeus, 1758) & Eu-Sib & Euryök & & 1 \\
\hline \multicolumn{5}{|l|}{ Thyatiridae } \\
\hline Habrosyne pyrithoides (Hufnagel, 1766) & Eu-Sib & Silvicol & 12 & \\
\hline Tethea ocularis (Linnaeus, 1758) & Eu-Sib & Pop-Salic. & 160 & \\
\hline Tethea or ([Den. et Schiff.], 1775) & Eu-Sib & Pop-Salic. & 142 & \\
\hline Thyatira batis (Linnaeus, 1758) & Eu-Sib & Silvicol & 124 & \\
\hline \multicolumn{5}{|l|}{ Geometridae } \\
\hline Angerona prunaria (Linnaeus, 1758) & Eu-Sib & Silvicol & & 1 \\
\hline Apeira syringaria (Linnaeus, 1758) & Eu-Sib & Lápr-Lápe. & 1 & \\
\hline Ascotis selenaria ([Den. et Schiff.], 1775) & Eu-Sib & Euryök & & 2 \\
\hline Cabera exanthemata (Scopoli, 1763) & Eu-Sib & Pop-Salic. & 1 & 2 \\
\hline Cabera pusaria (Linnaeus, 1758) & Eu-Sib & Lápr-Lápe. & & 2 \\
\hline Camptogramma bilineata (Linnaeus, 1758) & Eu-Sib & Sztyepp & & 32 \\
\hline Chlorochlysta siterata (Hufnagel, 1767) & Med & Pop-Salic. & & 2 \\
\hline Ectropis crepuscularia ([Den. et Schiff.], 1775) & Eu-Sib & Euryök & 2 & 24 \\
\hline Ennomos autumnaria (Werneburg, 1859) & Bor-Kont & Silvicol & 2 & 2 \\
\hline Epirrhoe alternata (Müller, 1764) & Eu-Sib & Euryök & 23 & 64 \\
\hline Hypomecis punctinalis (Scopoli, 1763) & Eu-Sib & Silvicol & 49 & 30 \\
\hline Hypomecis roboraria ([Den. et Schiff.], 1775) & Eu-Sib & Silvicol & 202 & 63 \\
\hline Idaea aversata (Linnaeus, 1758) & Med & Silvicol & 1 & 13 \\
\hline Idaea biselata (Hufnagel, 1767) & Eu-Sib & Lápr-Lápe. & & 1 \\
\hline Idaea dimidiata (Hufnagel, 1767) & Med & Euryök & & 2 \\
\hline Idaea muricata (Hufnagel, 1787) & Bor-Kont & Lápr-Lápe. & 14 & 7 \\
\hline Idaea ochrata (Scopoli, 1763) & Med & Sztyepp & & 4 \\
\hline Idaea rusticata ([ Den. et Schiff.], 1775) & Med & Silvicol & & 102 \\
\hline Idaea straminata (Borkhausen, 1794) & Eu-Sib & Silvicol & 1 & \\
\hline Ligdia adustata ([Den. et Schiff.], 1775) & Med & Silvicol & 1 & 55 \\
\hline Lomaspilis marginata (Linnaeus, 1758) & Eu-Sib & Nemorális & & 1 \\
\hline Lomographa temerata ([Den. et Schiff.], 1775) & Eu-Sib & Silvicol & & 1 \\
\hline Macaria alternata ([Den. et Schiff], 1775) & Eu-Sib & Nemorális & 1 & \\
\hline Macaria brunneata (Thunberg, 1784) & Bor-Kont & Altoherb. & & 1 \\
\hline Macaria liturata (Clerck, 1759) & Bor-Kont & Pinetális & & 99 \\
\hline
\end{tabular}




\begin{tabular}{|c|c|c|c|c|}
\hline Fajok & Faunaelem & $\begin{array}{c}\text { Fauna } \\
\text { komponens }\end{array}$ & FERM & FLORAL \\
\hline Macaria notata (Linnaeus, 1758) & Eu-Sib & Silvicol & 8 & 183 \\
\hline Orthonama obstipata (Fabricius, 1794) & Ext-Pal & Vándor & & 1 \\
\hline Peribatodes rhomboidaria ([Den. et Schiff], 1775) & Eu-Sib & Euryök & 3 & 3 \\
\hline Plagodis dolabraria (Linnaeus, 1767) & Eu-Sib & Silvicol & & 3 \\
\hline Plagodis pulveraria(Linnaeus, 1758) & Eu-Sib & Silvicol & & 1 \\
\hline Timandra comae (Schmidt, 1931) & Eu-Sib & Euryök & 1 & 1 \\
\hline Xantorrhoe fluctuata (Linnaeus, 1758) & Eu-Sib & Euryök & & 1 \\
\hline \multicolumn{5}{|l|}{ Notodontidae } \\
\hline Notodonta tritophus ([Den. et Schiff.], 1775) & Eu-Sib & Pop-Salic. & 1 & \\
\hline \multicolumn{5}{|l|}{ Erebidae } \\
\hline Catocala dilecta (Hübner, 1808) & Med & Quercetalis & 1 & \\
\hline Catocala electa (Vieweg, 1790) & Bor-Kont & Pop-Salic. & 9 & 2 \\
\hline Catocala elocata (Esper, 1788) & Eu-Sib & Pop-Salic. & 15 & \\
\hline Catocala fraxini (Linnaeus, 1758) & Bor-Kont & Pop-Salic. & 5 & \\
\hline Catocala fulminea (Scopoli, 1763) & Eu-Sib & Silvicol & 9 & 1 \\
\hline Catocala hymenaea ([Den. et Schiff.], 1775) & Med & Silvicol & 7 & \\
\hline Catocala nupta (Linnaeus, 1758) & Eu-Sib & Pop-Salic. & 44 & 3 \\
\hline Catocala promissa (Den. et Schiff., 1775) & Med & Quercetalis & 4 & \\
\hline Catocala puerpera (Giorna, 1791) & Med & Pop-Salic. & 1 & \\
\hline Catocala sponsa (Linnaeus, 1767) & Med & Quercetalis & 2 & \\
\hline Colobochyla salicalis (Den. et Schiff., 1775) & Eu-Sib & Pop-Salic. & & 2 \\
\hline Dysauxes ancilla (Linnaeus, 1767) & Med & Sztyepp & & 2 \\
\hline Eilema complana (Linnaeus, 1758) & Med & Zuzmóevő & & 10 \\
\hline Eilema depressa (Esper, [1787]) & Eu-Sib & Zuzmóevő & & 71 \\
\hline Eilema griseola (Hübner, 1803) & Bor-Kont & Lápr-Lápe. & 13 & 56 \\
\hline Eilema lurideola ([Zincken], 1817) & Eu-Sib & Zuzmóevő & & 63 \\
\hline Eilema lutarella (Linnaeus, 1758) & Eu-Sib & Zuzmóevő & & 3 \\
\hline Euclidia glyphica (Linnaeus, 1758) & Eu-Sib & Euryök & 11 & 1 \\
\hline Herminia grisealis ([Den. et Schiff.], 1775) & Eu-Sib & Euryök & 6 & \\
\hline Herminia tarsicrinalis (Knoch, 1782) & Eu-Sib & Avarevő & & 1 \\
\hline Herminia tarsipennalis (Treitschke, 1835) & Eu-Sib & Avarevő & 3 & 3 \\
\hline Herminia tenuialis (Rebel,1899) & P-Kasz-M & Lápr-Lápe. & 1 & \\
\hline Hypena proboscidalis (Linnaeus, 1758) & Eu-Sib & Mezofil & 110 & 119 \\
\hline Hypena rostralis (Linnaeus, 1758) & Eu-Sib & Euryök & 49 & 33 \\
\hline Lithosia quadra (Linnaeus, 1758) & Eu-Sib & Zuzmóevő & 7 & 3 \\
\hline Lygephila pastinum (Treitschke, 1826) & Med & Lápr-Lápe. & 5 & 2 \\
\hline Lygephila procax (Hübner, 1813) & Med & Quercetalis & 1 & \\
\hline Lymantria dispar (Linnaeus, 1758) & Eu-Sib & Silvicol & 1 & \\
\hline Lymantria monacha(Linnaeus, 1758) & Bor-Kont & Nemorális & 1 & \\
\hline Minucia lunaris ([Den. et Schiff.], 1775) & Med & Quercetalis & 7 & \\
\hline Paracolax tristalis (Fabricius, 1794) & Eu-Sib & Euryök & 1 & \\
\hline Parascotia fuliginaria (Linnaeus, 1761) & Eu-Sib & Fungivorous & & 1 \\
\hline Pelosia muscerda (Hufnagel, 1766) & Eu-Sib & Lápr-Lápe. & 68 & 22 \\
\hline Phragmatobia fuliginosa (Linnaeus, 1758) & Eu-Sib & Euryök & 3 & \\
\hline Polypogon tentacularia (Linnaeus, 1758) & Eu-Sib & Euryök & 19 & 5 \\
\hline
\end{tabular}




\begin{tabular}{|c|c|c|c|c|}
\hline Fajok & Faunaelem & $\begin{array}{c}\text { Fauna } \\
\text { komponens }\end{array}$ & FERM & FLORAL \\
\hline Rivula sericealis (Scopoli, 1763) & Eu-Sib & Euryök & & 5 \\
\hline Schrankia taenialis (Hübner, [1809]) & Med & Quercetalis & 1 & \\
\hline Scoliopteryx libatrix (Linnaeus, 1758) & Eu-Sib & Pop-Salic. & 46 & 1 \\
\hline Syntomis phegea (Linnaeus, 1758) & Eu-Sib & Euryök & 2 & 460 \\
\hline Wittia sororcula (Hufnagel, 1766)) & Med & Zuzmóevő & 42 & 94 \\
\hline \multicolumn{5}{|l|}{ Nolidae } \\
\hline Earias chlorana (Linnaeus, 1761) & Eu-Sib & Pop-Salic. & 2 & 4 \\
\hline Nola cristatula (Hübner, 1793) & Bor-Kont & Lápr-Lápe. & 1 & \\
\hline Nycteola degenerana (Hübner, 1799) & Eu-Sib & Pop-Salic. & 1 & \\
\hline \multicolumn{5}{|l|}{ Noctuidae } \\
\hline Abrostola agnorista Dufay, 1956 & Med & Sziklagyep & & 7 \\
\hline Abrostola asclepiadis ([Den. et Schiff.], 1775) & Eu-Sib & Altoherb. & & 6 \\
\hline Abrostola tripartita (Hufnagel, 1766) & Eu-Sib & Altoherb. & & 77 \\
\hline Abrostola triplasia (Linnaeus, 1758) & Eu-Sib & Altoherb. & & 56 \\
\hline Acontia trabealis (Scopoli, 1763) & Eu-Sib & Euryök & & 2 \\
\hline Acronicta auricoma ([Den. et Schiff.], 1775) & Bor-Kont & Silvicol & 1 & \\
\hline Acronicta euphorbiae ([Denis et Schiff], 1775) & Eu-Sib & Sztyepp & 21 & 1 \\
\hline Acronicta megacephala ([Den. et Schiff.], 1775) & Eu-Sib & Pop-Salic. & 58 & \\
\hline Acronicta psi (Linnaeus, 1758) & Eu-Sib & Pop-Salic. & 9 & \\
\hline Acronycta rumicis(Linnaeus, 1758) & Eu-Sib & Euryök & 138 & 6 \\
\hline Acronycta strigosa ([Den. et Schiff.], 1775) & Bor-Kont & Betulo-aln. & 2 & \\
\hline Actinotia polyodon (Clerck, 1759) & Bor-Kont & Nemorális & 3 & \\
\hline Agrochola circellaris (Hufnagel, 1766) & Eu-Sib & Silvicol & 111 & 5 \\
\hline Agrochola helvola (Linnaeus, 1758) & Eu-Sib & Silvicol & 214 & 1 \\
\hline Agrochola humilis ([Den. et Schiff.], 1775) & Med & Quercetalis & 8 & \\
\hline Agrochola laevis (Hübner, 1803) & Med & Quercetalis & 34 & \\
\hline Agrochola litura (Linnaeus, 1758) & Med & Quercetalis & 96 & 11 \\
\hline Agrochola lota (Clerck, 1759) & Eu-Sib & Pop-Salic. & 7 & \\
\hline Agrochola lychnidis ([Den. et Schiff.], 1775) & Eu-Sib & Silvicol & 3 & \\
\hline Agrochola macilenta (Hübner, 1803) & Med & Quercetalis & 72 & 1 \\
\hline Agrochola nitida ([Den. et Schiff.], 1775) & Med & Quercetalis & 9 & \\
\hline Agrotis bigramma (Esper, 1790) & Eu-Sib & Sztyepp & 10 & \\
\hline Agrotis cinerea ([Den. et Schiff.], 1775) & Med & Sztyepp & 4 & \\
\hline Agrotis clavis (Hufnagel, 1766) & Bor-Kont & Mezofil & 4 & \\
\hline Agrotis exclamationis (Linnaeus, 1758) & Eu-Sib & Euryök & 133 & 2 \\
\hline Agrotis ipsilon (Hufnagel, 1766) & Ext-Pal & Euryök & 37 & \\
\hline Agrotis segetum ([Den. et Schiff.], 1775) & Eu-Sib & Euryök & 164 & 3 \\
\hline Agrotis vestigialis (Hufnagel, 1766) & Bor-Kont & Pszammofil & 4 & 2 \\
\hline Allophyes oxyacanthae (Linnaeus, 1758 ) & Med & Silvicol & 83 & 4 \\
\hline Amphipyra berbera svenssoni (Fletcher, 1968) & Eu-Sib & Quercetalis & 1 & \\
\hline Amphipyra livida ([Den. et Schiff.], 1775) & Eu-Sib & Silvicol & 13 & 1 \\
\hline Amphipyra pyramidea (Linnaeus, 1758) & Eu-Sib & Euryök & 31 & \\
\hline Apamea anceps ([Den. et Schiff.], 1775) & Bor-Kont & Mezofil & 1 & \\
\hline Apamea lithoxylaea ([Den. et Schiff.], 1775) & Med & Sztyepp & 4 & \\
\hline Apamea monoglypha (Hufnagel, 1766) & Eu-Sib & Euryök & 64 & 3 \\
\hline
\end{tabular}




\begin{tabular}{|c|c|c|c|c|}
\hline Fajok & Faunaelem & $\begin{array}{c}\text { Fauna } \\
\text { komponens }\end{array}$ & FERM & FLORAL \\
\hline Aporophyla lutulenta ([Den. et Schiff.], 1775) & Med & Sztyepp & 5 & \\
\hline Apterogenum ypsillon ([Den. et Schiff.], 1775) & Bor-Kont & Pop-Salic. & 1 & \\
\hline Athetis furvula (Hübner, 1808) & Eu-Sib & Pszammofil & 2 & \\
\hline Athetis gluteosa (Treitschke, 1835) & Bor-Kont & Lápr-Lápe. & 7 & 5 \\
\hline Autographa gamma (Linnaeus, 1758) & Eu-Sib & Vándor & 1 & 173 \\
\hline Axylia putris (Linnaeus, 1761) & Med & Euryök & 2 & \\
\hline Blepharita satura ([Den. et Schiff.], 1775) & Eu-Sib & Silvicol & 5 & 2 \\
\hline Calamia tridens (Hufnagel, 1766) & Eu-Sib & Sztyepp & 1 & 8 \\
\hline Calophasia lunula (Hufnagel, 1766) & Eu-Sib & Sztyepp & & 28 \\
\hline Caradrina clavipalpis (Scopoli, 1763) & Eu-Sib & Euryök & 4 & 1 \\
\hline Caradrina gilva (Donzel, 1837) & Med & Sziklagyep & & 1 \\
\hline Caradrina morpheus (Hufnagel, 1766) & Eu-Sib & Euryök & 34 & 14 \\
\hline Charanyca trigrammica (Hufnagel, 1766) & Med & Sztyepp & 9 & \\
\hline Chilodes maritima (Tauscher, 1806) & Eu-Sib & Arundifil & & 1 \\
\hline Cirrhia gilvago ([Den. et Schiff.], 1775) & Eu-Sib & Pop-Salic. & 79 & \\
\hline Cirrhia icteritia (Hufnagel, 1766) & Eu-Sib & Pop-Salic. & 120 & 5 \\
\hline Cirrhia ocellaris (Borkhausen, 1792) & Eu-Sib & Pop-Salic. & 227 & 1 \\
\hline Colocasia coryli (Linnaeus, 1758) & Eu-Sib & Nemorális & 1 & \\
\hline Conistra erythrocephala ([Denis et Schiff], 1775) & Med & Quercetalis & 50 & 3 \\
\hline Conistra ligula (Esper, 1791) & Med & Quercetalis & 5 & \\
\hline Conistra rubiginosa (Scopoli, 1763) & Med & Quercetalis & 3 & \\
\hline Conistra vaccinii (Linnaeus, 1761) & Eu-Sib & Silvicol & 75 & \\
\hline Cosmia affinis (Linnaeus, 1767) & Eu-Sib & Silvicol & 3 & 1 \\
\hline Cosmia trapezina (Linnaeus, 1758) & Eu-Sib & Silvicol & 6 & \\
\hline Craniophora ligustri ([Den. et Schiff.], 1775) & Eu-Sib & Silvicol & 5 & 1 \\
\hline Cucullia umbratica (Linnaeus, 1758) & Eu-Sib & Euryök & & 2 \\
\hline Deltote bankiana (Fabricius, 1778) & Bor-Kont & Lápr-Lápe. & 1 & \\
\hline Diachrysia chrysitis (Linnaeus, 1758) & Eu-Sib & Altoherb. & & 12 \\
\hline Diachrysia stenochrysis (Warren, 1913) & Eu-Sib & Altoherb. & & 11 \\
\hline Diarsia rubi (Vieweg, 1790) & Eu-Sib & Lápr-Lápe. & 5 & \\
\hline Dichonia aprilina (Linnaeus, 1758) & Med & Quercetalis & 1 & \\
\hline Dypterygia scabriuscula (Linnaeus, 1758) & Eu-Sib & Silvicol & 712 & 15 \\
\hline Enargia paleacea (Esper, 1788) & Bor-Kont & Betulo-aln. & 5 & \\
\hline Epilecta linogrisea ([Den. et Schiff.], 1775) & Med & Quercetalis & 1 & \\
\hline Eucarta amethysthina (Hübner, 1803) & P-Kasz-M & Lápr-Lápe. & 2 & \\
\hline Eucarta virgo (Treitschke, 1825) & P-Kasz-M & Lápr-Lápe. & 1 & \\
\hline Euplexia lucipara (Linnaeus, 1758) & Eu-Sib & Silvicol & 27 & 2 \\
\hline Eupsilia transversa (Hufnagel, 1766) & Eu-Sib & Silvicol & 2 & \\
\hline Euxoa segnilis (Duponchel, 1837) & Med & Sztyepp & 7 & \\
\hline Euxoa tritici (Linnaeus, 1758) & Eu-Sib & Sztyepp & 2 & \\
\hline Globia algae (Esper, 1789) & Bor-Kont & Arundifil & 9 & \\
\hline Globia sparganii (Esper, 1790) & Eu-Sib & Arundifil & 3 & \\
\hline Hadula trifolii (Hufnagel, 1766) & Eu-Sib & Euryök & 1 & 2 \\
\hline Helicoverpa armigera (Hübner, 1808) & Ext-Pal & Vándor & 26 & 67 \\
\hline Heliophobus reticulata (Goeze, 1781) & P-Kasz-M & Mezofil & 1 & \\
\hline
\end{tabular}




\begin{tabular}{|c|c|c|c|c|}
\hline Fajok & Faunaelem & $\begin{array}{c}\text { Fauna } \\
\text { komponens }\end{array}$ & FERM & FLORAL \\
\hline Helotropha leucostigma (Hübner, [1808]) & Bor-Kont & Lápr-Lápe. & 1 & 1 \\
\hline Hoplodrina ambigua ([Den. et Schiff., 1775]) & Med & Euryök & 75 & 7 \\
\hline Hoplodrina blanda ([Den. et Schiff., 1775]) & Med & Silvicol & 9 & 2 \\
\hline Hoplodrina octogenaria (Goeze, 1781) & Eu-Sib & Silvicol & 4 & 9 \\
\hline Hoplodrina respersa ([Den. et Schiff.], 1775) & Med & Quercetalis & 1 & \\
\hline Lacanobia aliena (Hübner, 1809) & Eu-Sib & Sztyepp & & 1 \\
\hline Lacanobia oleracea (Linnaeus, 1758) & Eu-Sib & Euryök & 88 & 2 \\
\hline Lacanobia splendens (Hübner, 1808) & P-Kasz-M & Lápr-Lápe. & 1 & \\
\hline Lacanobia suasa ([Den. et Schiff.], 1775) & Eu-Sib & Euryök & 39 & \\
\hline Lacanobia thalassina (Hufnagel, 1766) & Eu-Sib & Silvicol & 289 & \\
\hline Lacanobia w-latinum (Hufnagel, 1766) & Med & Sztyepp & 1 & 1 \\
\hline Lithophane ornitopus (Hufnagel, 1766) & Eu-Sib & Euryök & 17 & \\
\hline Loscopia scolopacina (Esper, 1788) & Bor-Kont & Nemorális & 5 & \\
\hline Macdunnoughia confusa (Stephens, 1850) & Eu-Sib & Euryök & 1 & 178 \\
\hline Mamestra brassicae (Linnaeus, 1758) & Eu-Sib & Euryök & 53 & 4 \\
\hline Mesapamea secalis (Linnaeus, 1758) & Bor-Kont & Silvicol & 37 & \\
\hline Mesoligia furuncula ([Den. et Schiff.], 1775) & Eu-Sib & Silvicol & 14 & 1 \\
\hline Moma alpium (Osbeck, 1778) & Med & Quercetalis & 9 & \\
\hline Mythimna albipuncta ([Den. et Schiff.], 1775) & Eu-Sib & Mezofil & 131 & 9 \\
\hline Mythimna ferrago (Fabricius, 1787) & Eu-Sib & Altoherb. & 2 & \\
\hline Mythimna impura (Hübner, 1808) & Bor-Kont & Lápr-Lápe. & 2 & \\
\hline Mythimna I-album (Linnaeus, 1767) & Eu-Sib & Euryök & 11 & \\
\hline Mythimna pallens (Linnaeus, 1758) & Eu-Sib & Euryök & 27 & \\
\hline Mythimna pudorina ([Den. et Schiff.], 1775) & Bor-Kont & Lápr-Lápe. & 4 & \\
\hline Mythimna turca (Linnaeus, 1761) & Bor-Kont & Mezofil & 220 & 20 \\
\hline Mythimna vitellina (Hübner, 1808) & Eu-Sib & Euryök & 24 & 1 \\
\hline Naenia typica (Linnaeus, 1758) & Bor-Kont & Lápr-Lápe. & 5 & \\
\hline Noctua fimbriata (Schreber, 1759) & Med & Euryök & 57 & \\
\hline Noctua interjecta Hübner, 1803 & Med & Quercetalis & 7 & \\
\hline Noctua interposita (Hübner, 1790) & Med & Quercetalis & 5 & \\
\hline Noctua janthe (Borkhausen, 1792) & Med & Silvicol & 3 & \\
\hline Noctua janthina ([Den. et Schiff.], 1775) & Med & Euryök & 55 & \\
\hline Noctua orbona (Hufnagel, 1766) & Med & Sztyepp & 20 & 1 \\
\hline Noctua pronuba (Linnaeus, 1758) & Med & Euryök & 729 & 28 \\
\hline Ochropleura plecta (Linnaeus, 1761) & Eu-Sib & Euryök & 4 & \\
\hline Oligia latruncula ([Den. et Schiff.], 1775) & Eu-Sib & Euryök & 103 & 1 \\
\hline Oligia strigilis (Linnaeus, 1758) & Eu-Sib & Euryök & 10 & \\
\hline Orbona fragariae (Vieweg, 1790) & Eu-Sib & Altoherb. & 2 & \\
\hline Parastichtis suspecta (Hübner, 1817) & Eu-Sib & Pop-Salic. & 5 & \\
\hline Phlogophora meticulosa (Linnaeus, 1758) & Eu-Sib & Silvicol & 33 & 2 \\
\hline Phyllophila obliterata (Rambur, 1833) & Eu-Sib & Sztyepp & 18 & 4 \\
\hline Polia nebulosa (Hufnagel, 1766) & Bor-Kont & Altoherb. & 6 & \\
\hline Protodeltote pygarga (Hufnagel, 1766) & Eu-Sib & Euryök & 16 & \\
\hline Pseudeustrotia candidula ([Den. et Schiff.], 1775) & Bor-Kont & Euryök & 1 & \\
\hline Pyrrhia umbra (Hufnagel, 1766) & Eu-Sib & Silvicol & 4 & \\
\hline
\end{tabular}




\begin{tabular}{|l|c|c|c|c|}
\hline Fajok & Faunaelem & $\begin{array}{c}\text { Fauna } \\
\text { komponens }\end{array}$ & FERM & FLORAL \\
\hline Rhyacia simulans (Hufnagel, 1766) & Bor-Kont & Sztyepp & & 1 \\
\hline Rusina ferruginea (Esper, 1785) & Eu-Sib & Silvicol & 2 & \\
\hline Staurophora celsia (Linnaeus, 1758) & Eu-Sib & Sztyepp & 32 & 24 \\
\hline Thalpophila matura (Hufnagel, 1766) & Eu-Sib & Silvicol & 121 & 1 \\
\hline Tholera cespitis ([Den. et Schiff.], 1775) & Bor-Kont & Sztyepp & 10 & \\
\hline Tiliacea aurago (Den. et Schiff., 1775) & Med & Quercetalis & 8 & \\
\hline Tiliacea citrago (Linnaeus, 1758) & Med & Quercetalis & & 1 \\
\hline Trachea atriplicis (Linnaeus, 1758) & Eu-Sib & Silvicol & 248 & 2 \\
\hline Trichoplusia ni (Hübner, 1803) & Szubmed & Vándor & & 9 \\
\hline Xanthia togata (Esper, 1788) & Eu-Sib & Pop-Salic. & 10 & \\
\hline Xestia baja ([Den. et Schiff.], 1775) & Eu-Sib & Mezofil & 1 & \\
\hline Xestia c-nigrum (Linnaeus, 1758) & Eu-Sib & Euryök & 42 & 2 \\
\hline Xestia sexstrigata (Haworth, 1809) & Eu-Sib & Lápr-Lápe. & 15 & 1 \\
\hline Xestia stigmatica (Hübner, 1813) & Eu-Sib & Mezofil & 2 & \\
\hline Xestia triangulum (Hufnagel, 1766) & Med & Mezofil & 3 & \\
\hline Xestia xanthographa ([Den. et Schiff.], 1775) & Med & Mezofil & 464 & 5 \\
\hline Xylena exsoleta (Linnaeus, 1758) & Bor-Kont & Silvicol & 13 & \\
\hline Összesített fajszám (Sössz ) & & & 182 & 120 \\
\hline Összesített egyedszám (Nössz) & & & 7159 & 2532 \\
\hline
\end{tabular}

2. táblázat: $A$ Nagycserén fogott Macroheterocera fajok száma családonként, illetve bagolylepke (Noctuidae) alcsaládonként, a használt illatanyagok szerint külön-külön (FERM, FLORAL) és összesítve (Össz.), valamint az illatanyagok által együttesen (Közös) és az egyik, vagy másik illatanyag által kizárólagosan fogott (differenciális-Diff) fajok számai.

\begin{tabular}{lcccccc} 
& FLORAL & FERM & Össz. & Diff $_{\text {FLORAL }}$ & Diff $_{\text {FERM }}$ & Közös \\
\hline Sphingidae & 1 & 1 & 2 & 1 & 1 & 0 \\
Thyatiridae & 0 & 4 & 4 & 0 & 4 & 0 \\
Geometridae & 29 & 15 & 32 & 17 & 3 & 12 \\
Notodontidae & 0 & 1 & 1 & 0 & 1 & 0 \\
Erebidae & 24 & 31 & 40 & 9 & 16 & 15 \\
Nolidae & 1 & 3 & 3 & 0 & 2 & 1 \\
Noctuidae & 67 & 128 & 144 & 16 & 77 & 51 \\
\hline Xyleninae & 29 & 60 & 63 & 3 & 34 & 26 \\
Noctuinae & 9 & 27 & 28 & 1 & 19 & 8 \\
Hadeninae & 8 & 18 & 19 & 1 & 11 & 7 \\
Plusiinae & 10 & 2 & 10 & 8 & 0 & 2 \\
Acronictinae & 3 & 8 & 8 & 0 & 5 & 3 \\
Egyéb alcsaládok & 8 & 13 & 16 & 3 & 8 & 5 \\
\hline Lepkék összesen & 122 & 183 & 226 & 43 & 104 & 79 \\
\hline
\end{tabular}




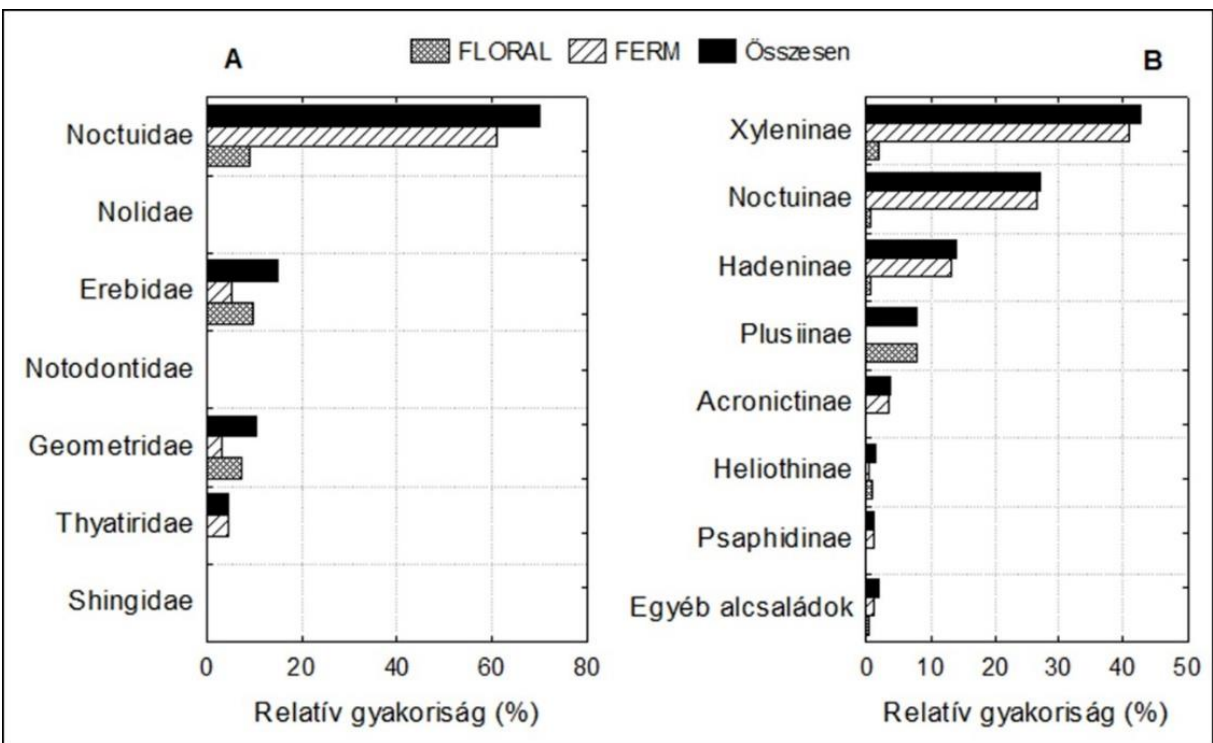

1. ábra: A gyüjtött lepkék fogott egyedszámok alapján számolt családonkénti, illetve a bagolylepkék alcsaládonkénti relatív gyakoriságai (\%) a két használt illatanyag (FLORAL, FERM) esetén külön-külön és összesitve.

A vizsgálat rövid időtartama, az alkalmazott módszer és a viszonylag csekély fogott fajszám ellenére a Nagycserén végzett mintavételek több érdekes és értékes adattal járultak hozzá a Dél-Nyírség lepkefaunájának ismeretéhez. Több olyan fajt sikerült befogni, melyek jelenléte váratlan a területen, illetve általában véve az Alföld egész területén ritkának számítanak. Ezek a fajok kivétel nélkül bagolylepkék, jellemzésük taxonómiai sorrendben:

Herminia tenuialis (Rebel,1899) - nagy, diszjunkt elterjedésű déli kontinentális faj, lokális hazai előfordulású, föleg nedves, üde láperdők lakója. Hernyója avarfogyasztó.

Catocala fraxini (Linnaeus, 1758) - a legnagyobb méretü közép-európai bagolylepke. Nagy elterjedésü, de sehol sem gyakori. Hernyója polifág, fásszárúakon fejlődik (Mészáros \& Szabóky 2012). Védett.

Catocala dilecta (Hübner, 1808) - széles, mediterrán elterjedésű faj, hazánkban nagyon szórványos megjelenésű. Meleg, száraz tölgyesek lakója. Hernyója tölgyön fejlődik. Jelenléte a vizsgálati területen fennmaradt elegyes tölgyerdőknek köszönhető. Védett.

Catocala hymenaea ([Denis \& Schiffermüller], 1775) - széles elterjedésű faj, hazánkban föleg az alacsonyabb hegy- és dombvidékek lakója, az Alföldön lokális. Száraz tölgyesek és erdőszegélyek lakója. Hernyója Rosaceae családba tartozó cserjéken (Prunus, Crataegus) fejlödik.

Eucarta amethystina (Hübner, 1803) - nagy elterjedésű, hazánkban az Észak-Alföldön és a Nyírségben szinte mindenhol előfordul, és helyenként (pl. Bátorliget, Beregi-sík) gyakori is. 
Nedvességigényes, mocsár- és lápréteken, üde erdőtisztásokon fordul elő. Hernyója ernyősvirágzatúakon fejlödik.

Eucarta virgo (Treitschke, 1825) - az előzőhöz hasonló elterjedésű és életmódú, de attól gyakoribb előfordulású faj, ami kevésbé kötődik a nedves élőhelyekhez. Hernyója lágyszárúakon fejlődik.

Helotropha leucostigma (Hübner, [1808]) - széles elterjedésű faj, föleg mocsár- és lápréteken fordul elő. Nálunk lokális előfordulású. Hernyója lágyszárúakon fejlődik.

Staurophora celsia (Linnaeus, 1758) - széles elterjedésű, de csak szórványos előfordulású faj. Magyarországon föleg a homokvidékeken elterjedt. A hernyói pázsitfüveken fejlődnek (Mészáros \& Szabóky 2012). Védett.

Enargia paleacea (Esper, 1788) - nagy elterjedésű, de lokális elöfordulású faj. Magyarországon ritka, elsősorban hegyvidékek lakója, az Alföldről csak kevés helyröl ismert. Hernyója föleg nyíren fejlődik.

Xylena exsoleta (Linnaeus, 1758) - nagy elterjedésü, Magyarországon szinte mindenütt elöfordul, de sehol sem tömeges. Polifág, hernyója különböző lágyszárúakon fejlödik (Ronkay \& Ronkay 2006).

Orbona fragariae (Vieweg, 1790) - nagy elterjedésű faj, azonban mindenhol elég lokális és ritka. Magyarországról eddig csak kevés lelőhelye ismert, az Alföldön ritkaságszámba megy. Élőhelyei föleg nedves és hüvös, dús aljnövényzetű erdőterületek. Tápnövényei apróbb kétsziküek (Ronkay \& Ronkay 2006). Védett.

Euxoa segnilis (Duponchel, 1837) - nagy elterjedésü, szaggatott áreájú (félsivatagok, homokdünék) faj, jellemzően homokterületeinken fordul elö. Polifág, hernyója különböző lágyszárúakon fejlődik (Ronkay \& Ronkay 2006).

Diarsia rubi (Vieweg, 1790) - széles elterjedésü, de nem gyakori, az Alföldön csak lokális előfordulású. Nedvességigényes, főleg láperdőkben, lápréteken él. Érdekessége, hogy eddigi ismereteink szerint a csalétkek iránt többé-kevésbé közömbös! Polifág, hernyója különböző lágyszárúakon fejlődik (Ronkay\& Ronkay 2006).

Agrotis vestigialis (Hufnagel, 1766) - széles elterjedésű faj, hazánkban homokterületeken tömeges lehet, más élöhelyeken csak szórványos. Polifág, föleg lágyszárúak gyökereit fogyasztja. Az Alföldröl eddig csak kevés adata ismert (Szabóky \& Leskó 1999).

Xestia sexstrigata (Haworth, 1809) - széles elterjedésű, de lokális előfordulású faj, korábban csak magashegyi tőzeglápokról, nagyobb mocsárvidékekről ismerték, ezért magyarországi megjelenése meglepő volt. A síkvidékekről a korábbi intenzív kutatások alkalmával nem került elö, az 1990-es évek végén azonban megfigyelhető volt a terjedése. Azóta számos síkvidéki területröl igazolták jelenlétét. Hernyója különböző lágyszárúakon fejlődik (Ronkay \& Ronkay 2006). Védett. 
Naenia typica (Linnaeus, 1758) - nagy elterjedésü, azonban nálunk csak szórványosan előforduló faj. Nedvességigényes, föleg mocsárerdők és mocsárrétek jellemző faja. Polifág, hernyója különböző lágyszárúakon fejlődik (Ronkay \& Ronkay 2006). Védett.

A fogott faunisztikailag jelentős és védett fajok között sok nedvességigényes, illetve kifejezetten homokterületekhez kötődő faj is megjelent a mintákban. Ez jól jelzi a vizsgált terület, illetve általában a Dél-Nyírség élőhelyeinek mozaikosságát, a vegetáció összetételének változatosságát: az erdők és rétek mélyebben fekvő részeinek időszakos vízborítását, a buckaközi laposokon jellegzetes láprétek és a magasabb térszínek, peremterületek homoki gyepjeinek együttes jelenlétét. A nedvességigényes fajok magas száma jól mutatja, hogy a Dél-Nyírség a klíma elmúlt évtizedekben tapasztalható folyamatos melegedése (szárazodása) és a néhol intenzív tájhasználat (szántók, legelők) ellenére legalább részben képes volt megörizni korábbi karakterét.

A vizsgált fauna állatföldrajzi szempontból jól jellemezhetők a faunaelemek megoszlása alapján (2A. ábra). A gyüjtött anyag zömét a széles ökológiai türőképességü euroszibériai elterjedésű fajok adták, amelyek a Kárpát-medencében általánosan elterjedtek, és általában gyakoriak is. Dominanciájuk nem meglepő, mivel a mintaterület környékének jelentős része bolygatott, vagy valamilyen kezelés alatt áll, ami számukra kedvező. Figyelemreméltó azonban, hogy az euroszibériai jellegü alapfauna mellett a fajok közel egyharmada valamilyen állatföldrajzi színezőelemnek tekinthetö. Közülük a legjelentősebbek a mediterrán faunaelemek (Lygephila procax, Minucia lunaris, Catocala dilecta, Catocala puerpera, Epilecta linogrisea), de nagy volt a Kárpát-medencében zömmel hegyvidéki elterjedésű boreo-kontinentális („szibériai”) fajok száma is (pl.: Macaria liturata, Athetis gluteosa, Helotropha leucostigma), sőt több déli-kontinentális, ligeterdei és nedves réti élőhelyekhez kötött faj (Herminia tenuialis, Eucarta amethysthina, Eucarta virgo) jelenléte is kimutatható volt.

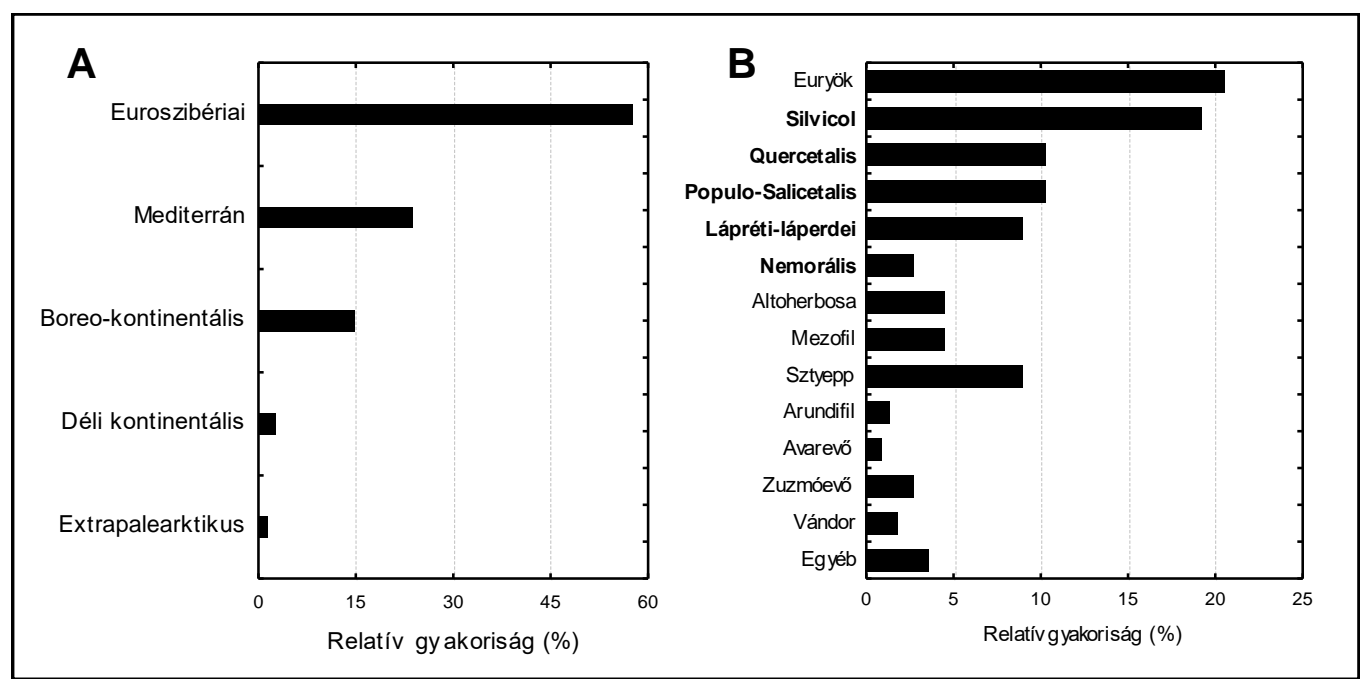

2. ábra: A gyüjtött fajok faunaelem (A) és faunakomponens (B) szerinti megoszlása a fogott egyedszámokból számolt relatív gyakoriságok alapján. Félkövér (B): lomberedei csoportok. 
A terület növényzeti adottságait figyelembe véve az euryök fajok nagy részaránya volt várható. Az erdei élőhelyekhez kötődő fajok közül jelentősebbek a silvicol, a quercetális és a populo-salicetális lomberdei fajok voltak (pl: Dypterygia scabriuscula, Allophyes oxyacanthae, Agrochola litura, A. macilenta, Cirrhia ocellaris, C. icteritia). Természetközeli gyepterületek kisebb arányban vannak jelen a területen, mint az erdők, amit a sztyeppei elemek alacsonyabb részesedése is jól mutatott.

A vizsgálati időszakok során gyüjtött fajok közel 20\%-a (39 faj) tartozik a potenciális kártevők közé (3. táblázat). Ugyan a legnagyobb veszélyt jelentő, a bagolylepke-családsorozatba (Noctuoidea) tartozó gyapjaslepkeformák két képviselője is jelen van (Lymantria dispar, L. monacha), azonban részesedési arányuk elenyésző (0,01-0,01\%) volt a vizsgált időszakban. Az 1\% feletti relatív gyakorisági értékekkel rendelkező abundáns fajok tömeges fellépése nem zárható ki, amely különböző mértékű károkat okozhat.

3. táblázat: A Debrecen-Nagycserén 2014-ben és 2015-ben illatanyagos csapdákkal gyüjtött abundáns lepkefajok faunaelem és faunakomponens besorolása (Id. még 1. táblázat) és az összesitett fogott egyedszámok alapján számolt relatív gyakoriságai (\%) csapdatípusonként.

\begin{tabular}{|c|c|c|c|c|}
\hline Fajok & Faunaelem & Faunakomponens & FERM & $\begin{array}{l}\text { FLO- } \\
\text { RAL }\end{array}$ \\
\hline \multicolumn{5}{|l|}{ Thyatiridae } \\
\hline Thyatira batis (Linnaeus, 1758) & Eu-Sib & Silvicol & 1,73 & 0,00 \\
\hline Tethea ocularis (Linnaeus, 1758) & Eu-Sib & Pop-Salic. & 2,24 & 0,00 \\
\hline Tethea or ([Den. et Schiff.], 1775) & Eu-Sib & Pop-Salic. & 1,98 & 0,00 \\
\hline \multicolumn{5}{|l|}{ Geometridae } \\
\hline Cabera pusaria (Linnaeus, 1758) & Eu-Sib & Lápr-Lápe. & 0,00 & 0,08 \\
\hline Chlorochlysta siterata (Hufnagel, 1767) & Med & Pop-Salic. & 0,00 & 0,08 \\
\hline Ectropis crepuscularia ([Den. et Schiff.], 1775) & Eu-Sib & Euryök & 0,03 & 0,95 \\
\hline Hypomecis punctinalis (Scopoli, 1763) & Eu-Sib & Silvicol & 0,68 & 1,18 \\
\hline Hypomecis roboraria ([Den. et Schiff.], 1775) & Eu-Sib & Silvicol & 2,82 & 2,49 \\
\hline Lomaspilis marginata (Linnaeus, 1758) & Eu-Sib & Nemorális & 0,00 & 0,04 \\
\hline Peribatodes rhomboidaria ([Den. et Schiff], 1775) & Eu-Sib & Euryök & 0,04 & 0,12 \\
\hline Plagodis dolabraria (Linnaeus, 1767) & Eu-Sib & Silvicol & 0,00 & 0,12 \\
\hline \multicolumn{5}{|l|}{ Notodontidae } \\
\hline Notodonta tritophus ([Den. et Schiff.], 1775) & Eu-Sib & Pop-Salic. & 0,01 & 0,00 \\
\hline \multicolumn{5}{|l|}{ Erebidae } \\
\hline Catocala fraxini (Linnaeus, 1758) & Bor-Kont & Pop-Salic. & 0,07 & 0,00 \\
\hline Lithosia quadra (Linnaeus, 1758) & Eu-Sib & Zuzmóevő & 0,10 & 0,12 \\
\hline Lymantria dispar (Linnaeus, 1758) & Eu-Sib & Silvicol & 0,01 & 0,00 \\
\hline Lymantria monacha (Linnaeus, 1758) & Bor-Kont & Nemorális & 0,01 & 0,00 \\
\hline Minucia lunaris ([Den. et Schiff.], 1775) & Med & Quercetalis & 0,10 & 0,00 \\
\hline Scoliopteryx libatrix (Linnaeus, 1758) & Eu-Sib & Pop-Salic. & 0,64 & 0,04 \\
\hline \multicolumn{5}{|l|}{ Nolidae } \\
\hline Earias chlorana (Linnaeus, 1761) & Eu-Sib & Pop-Salic. & 0,03 & 0,16 \\
\hline
\end{tabular}




\begin{tabular}{|l|c|c|c|c|}
\hline Fajok & Faunaelem & Faunakomponens & FERM & $\begin{array}{c}\text { FLO- } \\
\text { RAL }\end{array}$ \\
& & & & \\
\hline \multicolumn{2}{|l|}{ Noctuidae } & & & \\
\hline Acronicta megacephala ([Den. et Schiff.], 1775) & Eu-Sib & Pop-Salic. & 0,81 & 0,00 \\
\hline Acronycta rumicis (Linnaeus, 1758) & Eu-Sib & Euryök & $\mathbf{1 , 9 3}$ & 0,24 \\
\hline Agrochola circellaris (Hufnagel, 1766) & Eu-Sib & Silvicol & $\mathbf{1 , 5 5}$ & 0,20 \\
\hline Agrotis exclamationis (Linnaeus, 1758) & Eu-Sib & Euryök & $\mathbf{1 , 8 6}$ & 0,08 \\
\hline Agrotis segetum ([Den. et Schiff.], 1775) & Eu-Sib & Euryök & $\mathbf{2 , 2 9}$ & 0,12 \\
\hline Allophyes oxyacanthae (Linnaeus, 1758) & Med & Silvicol & $\mathbf{1 , 1 6}$ & 0,16 \\
\hline Colocasia coryli (Linnaeus, 1758) & Eu-Sib & Nemorális & 0,01 & 0,00 \\
\hline Conistra vaccinii (Linnaeus, 1761) & Eu-Sib & Silvicol & $\mathbf{1 , 0 5}$ & 0,00 \\
\hline Cosmia trapezina (Linnaeus, 1758) & Eu-Sib & Silvicol & 0,08 & 0,00 \\
\hline Helicoverpa armigera (Hübner, 1808) & Ext-Pal & Vándor & 0,36 & $\mathbf{2 , 6 5}$ \\
\hline Lacanobia oleracea (Linnaeus, 1758) & Eu-Sib & Euryök & $\mathbf{1 , 2 3}$ & 0,08 \\
\hline Lacanobia suasa ([Den. et Schiff.], 1775) & Eu-Sib & Euryök & 0,54 & 0,00 \\
\hline Mamestra brassicae (Linnaeus, 1758) & Eu-Sib & Euryök & 0,74 & 0,16 \\
\hline Phlogophora meticulosa (Linnaeus, 1758) & Eu-Sib & Silvicol & 0,46 & 0,08 \\
\hline
\end{tabular}

Thyatira batis (Linnaeus, 1758) - széles elterjedésü, kétnemzedékes faj. Tápnövényei a Rubus-félék közül kerülnek ki. Két nemzedéke május és június fordulóján, valamint augusztus-szeptemberben repül. A talajban báb alakban telel (Szabóky \& Leskó 1999).

Tethea ocularis (Linnaeus, 1758) / Tethea or ([Denis et Schiffermüller], 1775) - az elöző fajhoz hasonlóan széles elterjedésüek, hernyóik nyárakon és füzeken fejlődnek. Mindkét faj kétnemzedékes. Számottevő kártételükre még nem volt példa (Szabóky \& Leskó 1999, Zúbrik et al 2013).

Hypomecis roboraria ([Denis et Schiffermüller], 1775) - Széles elterjedésű faj, lombos erdőkben gyakori. Egynemzedékü. A pete telel át, a hernyók tavasszal lombos fákon fejlődnek, leginkább tölgy fajokon táplálkozik (Mészáros \& Szabóky 2012).

Hypomecis punctinalis (Scopoli, 1763) - Az előző fajhoz hasonló elterjedésű és életmódú faj. Kétnemzedékü, a hernyók május és szeptember között táplálkoznak, föleg tölgy fajokon (Mészáros \& Szabóky 2012).

Allophyes oxyacanthae (Linnaeus, 1758) - egész Európában megtalálható, hazánkban szinte mindenhol előfordul. Egynemzedékes, szeptember elejétől repül. A hernyó a galagonya, a kökény és a körte fajokon fejlödik (Zúbrik et al 2013).

Acronicta rumicis (Linnaeus, 1758) - Egész Eurázsiában általánosan elterjedt, Magyarországon gyakori. Hazánkban háromnemzedékü, az első egyedek már április elejétől repülnek. A hernyók polifágok, május végétöl októberig folyamatosan megtalálhatóak. Különböző 
mértékủ kártétele megfigyelhető volt már fiatal füz- és nyárfákon, gyümölcsfákon, rózsán stb. (Mészáros \& Szabóky 2012).

Helicoverpa armigera (Hübner, 1808) - Vándor faj, első megjelenése után októberig szinte folyamatosan tenyészik, melegebb években át is telelhet. Polifág, a hernyók számos termesztett és vadon termő növény károsítói. Leginkább a mezőgazdasági termesztésben okoz károkat (Mészáros \& Szabóky 2012), de akác, nemes nyár és tölgy fiatalosokban is egyre gyakrabban észlelik tömeges jelenlétét és lombrágását (Csóka et al 2013)

Conistra vaccinii (Linnaeus, 1761) - Egész Európában elterjedt, polifág faj. Tápnövényei többek között a tölgy, hárs, juhar, szil, füz, galagonya stb. A hernyó május-június folyamán táplálkozik. A fiatal hernyó a rügyeket és a virágokat rágja (Szabóky \& Leskó 1999).

Agrochola circellaris (Hufnagel, 1766) - szintén egész Európában elterjedt, polifág faj. Főbb tápnövényei a füz, nyár, szil, bükk, nyír stb. fajok közül kerülnek ki. A hernyók március-április folyamán táplálkoznak, eleinte virágrügyeket, virágokat, terméskezdeményeket, később pedig lágyszárú növényeket fogyaszt (Szabóky \& Leskó 1999).

Agrotis segetum ([Denis et Schiffermüller], 1775) - általánosan elterjedt, polifág faj. Erdészeti faikolákban a bükk, a tölgy, a gyertyán, a füz, a fenyő stb. csemetéit károsithatja. $\mathrm{A}$ mezőgazdaságban szinte minden kultúrnövényt károsithat. Kétnemzedékes, a nemzedékek összefolyhatnak. Fejlett hernyóként telel, a telelés előtti hernyónemzedék kártétele nagyobb (Szabóky \& Leskó 1999).

Agrotis exclamationis (Linnaeus, 1758) - az elözöhöz hasonlóan általánosan elterjedt, polifág, erdészetekben föleg fenyő, szil és juhar fajokon él. Hernyói nyáron és ősszel táplálkoznak. Szintén fejlett hernyóként telel. Leginkább fiatal telepitésü erdőkben és csemetekertben okozhat kárt (Szabóky \& Leskó 1999, Zúbrik et al 2013).

A lepkefauna vizsgálata összességében azt a már ismert tényt igazolta, hogy a Nyírség faunájában az erdei elemek dominálnak, hiszen a Nyírség, az Alföld nagy részétől eltérően, nem erdőssztyepp-táj, hanem már klímazonális erdőterület. Vizsgálataink is megerősítették, hogy az erdőlakó fajok közt van a legtöbb állatföldrajzi színezőelem, illetve védett faj is. Ettöl az általános képtöl a magasabb fekvésű, mélyebb talajvízszintü buckás élőhelyek térnek el jelentősen, ahol mérsékelt számban megjelennek a homoki élőhelyek specialistái. Bár a használt illatanyagok, nagy számban képesek azokat csalogatni (Szanyi et al 2015, 2017, Nagy et al 2014, 2015a, 2015b) az agrár-, illetve erdészeti kártevők csak kisebb számban jelentkeztek, hisz a területen nincsen olyan arányban jelen a nagytáblás növénytermesztés, ami tömeges fellépésüket indokolta volna.

A lepkefauna alapján a terület továbbra is őrzi a rá természetesen jellemző fauna és flóra vonásait, amit számos tényező, köztük a kedvezőtlen tájhasználat (idegenhonos fafajok telepítése, mezőgazdasági intenzifikáció) és a klímaváltozás egyaránt veszélyeztet. A nagy fajgazdagságú, unikális, a különböző faunaelemek és faunakomponensek sajátos keverékét 
mutató fauna megóvása azonban további kutatásokat és az azok alapján tervezett tájhasználatot és természetvédelmi fenntartó kezelést feltételez.

\section{KÖSZÖNETNYILVÁNÍTÁS}

\section{Szanyi Szabolcs munkáját az MTA Domus Junior ösztöndíja támogatta.}

\section{FELHASZNÁLT IRODALOM}

Abafi-Aigner L. 1907: Magyarország lepkéi tekintettel Európa többi országainak lepke-faunájára. Királyi Magyar Természettudományi Társulat, Budapest.

Ács E., Bálint Zs., Ronkay G., Ronkay L., Szabóky Cs., Varga Z. et al. 1991: The Lepidoptera of the Bátorliget nature Conservation Area. In: Mahunka S. (ed): The Bátorliget Nature Reserve-after forty years. Hungarian Natural History Museum, Budapest, 505-540.

Baranyi T. 2003: A keleti lápibagoly (Arytrura musculus) és a Metelka-medvelepke (Rhyparioides flavidus metelkanus) elöfordulásai a Dél-Nyírségben (Lepidoptera). Folia Entomologica Hungarica 48: 357-361.

Baranyi T. \& Bertalan L. 2002: A Hanelek, a Mogyorósi-erdő (Teleki-legelő), a Káposztás-lapos és a Jónásrész Nagylepkefaunájának (Macrolepidoptera) vizsgálata. A Puszta 19(1): 23-66.

Baranyi T., Józsa Á.Cs. \& Korompai T. 2005: 2006. évi adatok a Tiszántúl és a Tisza-mente Lepidopterafaunáának ismeretéhez (Lepidoptera). A Puszta 22(1): 29-112.

Baranyi T., Korompai T., Józsa Á. Cs. \& Bertalan L. 2004: Adatok a Tiszántúl és a Tisza-mente Lepidopterafaunájának ismeretéhez (Lepidoptera). A Puszta 21(1): 21-134.

Boros Á. 1932: A Nyírség flórája és növényföldrajza. Tisza István Tudományos Társaság Honismerteti Bizottságának Kiadványai VIII., Debrecen, 208.

Cantelo W.W. \& Jacobson M. 1979: Phenylacetaldehyde attracts moths to bladder flower and blacklight traps. Environmental Entomology 8: 444-447. DOI: 10.1093/ee/8.3.444

Csóka Gy., Hirka A., Koltay A. \& Kolozs L. 2013: Erdőkárok - képes útmutató. NÉBIH Erdészeti Igazgatósága és az Erdészeti Tudományos Intézet, Budapest.

Kelecsényi K. 1885: Éjjeli lepkevadászat Nyitramegyében. Rovartani Lapok 2: 71-74.

Kovács L. 1953: Bátorliget nagylepke-faunája. Macrolepidoptera. In: Székessy V. (ed): Bátorliget élővilága. Akadémiai kiadó, Budapest, 326-380.

Landolt P.J. 2000: New chemical attractants for trapping Lacanobia subjuncta, Mamestra configurata, and Xestia c-nigrum (Lepidoptera: Noctuidae). Journal of Economical Entomology 93: 101-106. DOI: 10.1603/0022-0493-93.1.101

Landolt P.J. \& Alfaro J.F. 2001: Trapping Lacanobia subjuncta, Xestia c-nigrum and Mamestra configurata (Lepidoptera: Noctuidae) with acetic acid and 3-methyl-1-butanol in controlled relesase dispensers. Environmental Entomology 30: 656-662. DOI: 10.1603/0046-225x-30.4.656

Matus G. \& Papp M. 2003: Adatok Hajdúsámson és Vámospércs környékének (Dél-Nyírség) flórájához. Kitaibelia 8(1): 99-112.

Mészáros Z. \& Szabóky Cs. 2012: A magyarországi nagylepkék gyakorlati albuma. Szalkay József Magyar Lepkészeti Egyesület, Budapest.

Mészáros Z. \& Vojnits A. 1972: Lepkék, pillék, pillangók. Natura. Budapest.

Nagy A., Szarukán I., Gém F., Nyitrai R. \& Tóth M. 2014: Vizsgálatok bagolylepkék (Lepidoptera: Noctuidae) fogására kifejlesztett szintetikus illatanyag csalétkek hatékonyságának növelésére. Acta Agraria Debreceniensis 62: 86-91. DOI: $10.34101 /$ actaagrar/62/2174

Nagy A., Szarukán I., Gém F., Nyitrai R., Füsti-Molnár B., Németh A., et al. 2015a: Preliminary data on the effect of semi-synthetic baits for Noctuidae (Lepidoptera) on the non-taget Lepidoptera species. Acta Agraria Debreceniensis 66: 71-80. DOI: 10.34101/actaagrar/66/1895 
Nagy A., Szarukán I., Szanyi Sz., Kozák L., Füsti-Molnár B., Varga Z. et al. 2015b: Bagolylepkék Illatanyagokkal történő csapdázásának eredményei Hajdú-Bihar megyei területeken. In: Bakonyi I. (ed): X. Növényorvos nap. Konferencia helye, ideje: Budapest, 2015.11.11. Magyar Növényvédö Mérnöki és Növényorvosi Kamara, 78-79.

Papp L. \& Dudás M. 1989a: Adatok a Közép-, a Dél-Nyírség és környékének botanikai értékeiröl I. Calandrella 2(2): $5-25$.

Papp L. \& Dudás M. 1989b: Adatok a Közép-, a Dél-Nyírség és környékének botanikai értékeiről II. Calandrella 3(2): 13-33.

Petrich K. 2001: A velencei táj lepkevilága. Mezőgazdasági Szaktudás Kiadó, Budapest.

Ronkay G. \& Ronkay L. 2006: A magyarországi csuklyás-, szegfü- és földibaglyok atlasza. Natura Somogyiensis 8: 1-416.

Soó R. 1934: Nyírség-kutatásunk florisztikai eredményei. Botanikai Közlemények 31(5-6): 218-250.

Soó R. 1937: Pótlékok nyírségi flórakutatásunk eredményeihez. Botanikai Közlemények 34(1-2): 33-44.

Soó R. 1938: Vízi, mocsári és réti növényszövetkezetek a Nyírségben. Botanikai Közlemények 35(5-6): 250272.

Soó R. 1939a: Pótlékok nyírségi flórakutatásunk eredményeihez II. Botanikai Közlemények 36(5-6): 307-312.

Soó R. 1939b: A Nyírség vegetációja III. A Nyírség pusztai növényszövetkezetei. MTA Matematikai és Természettudományi Értesítő 58: 833-844.

Soó R. 1943: A nyírségi erdök a növényszövetkezetek rendszerében. Acta Geobotanica Hungarica 5: 315352.

Szabóky Cs. \& Leskó K. 1999: Lepidoptera - Lepkék. In: Tóth J. (ed): Erdészeti rovartan. Agroinform kiadó, Budapest, 307-409.

Szanyi Sz., Nagy A., Molnár A., Tóth M. \& Varga Z. 2015: Pest species of Macrolepidoptera in the Game Reserve of Velyka Dobron' (Transcarpathia, Ukraine). Acta Agraria Debreceniensis 65: 58-64. DOI: 10.34101/actaagrar/66/1893

Szanyi Sz., Nagy A., Molnár A., Katona K., Tóth M. \& Varga Z. 2017: Night-active Macroheterocera species in traps with synthetic attractants in the Velyka Dobron' Game Reserve (Ukraine, Transcarpathia). Acta Zoologica Academiae Scientiarum Hungaricae 63(1): 97-114. DOI: 10.17109/azh.63.1.97.2017

Tóth M., Szarukán I., Dorogi B., Gulyás A., Nagy P. \& Rozgonyi Z. 2010: Male and female Noctuid moths attracted to synthetic lures in Europe. Journal of Chemical Ecology 36: 592-598. DOI: 10.1007/s10886010-9789-z

Tóth M., Szarukán I., Nagy A., Gém F., Nyitrai R., Kecskés Zs., et al. 2015: Félszintetikus „biszex” csalétkek kártevő rovarok nőstényeinek és hímjeinek fogására. Növényvédelem 51: 197-205.

Varga Z. 1957: Debrecen és környéke nagylepkefaunája. Folia Entomologica Hungarica 10: 235-258.

Varga Z. 1960a: Debrecen környéke nagylepke-faunájának állatföldrajzi elemzése. Folia Entomologica Hungarica 13: 69-123.

Varga, Z. 1960b: Újabb adatok Debrecen környéke nagylepke-faunájához. Folia Entomologica Hungarica 13: 537-542.

Varga Z. 1962: A Nyírség déli része Macrolepidoptera faunája. Calandrella, Debrecen.

Varga Z. (ed.) 2011: Magyarország nagylepkéi - Macrolepidoptera of Hungary. Heterocera Press, Budapest.

Varga Z., Ronkay L., Bálint Zs., László M.Gy. \& Peregovits L. 2004: Checklist of the fauna of Hungary. Volume 3. Macrolepidoptera. Hungarian Natural History Museum, Budapest, 106.

Zúbrik M., Kunca A. \& Csóka Gy. 2013: Insect and diseases damaging trees and shrubs of Europe - A Colour Atlas. NAP Editions.

Érkezett: 2019. április 29.

Közlésre elfogadva: 2019. szeptember 3. 